\title{
Angewandte
}

Supporting Information

(c) Wiley-VCH 2005

69451 Weinheim, Germany 


\section{Controlled assembly of macromolecular $\beta$-sheet fibrils}

Jurgen M. Smeenk, Matthijs B. J. Otten, Jens Thies, David A. Tirrell, Hendrik G. Stunnenberg, and Jan C. M. van Hest*

\section{Contents}

Materials and methods

Protein expression and purification

Synthesis of maleimide-functionalized poly(ethylene glycol)-750

Conjugation of PEG-750-maleimide to $\left[(\mathrm{AG})_{3} \mathrm{EG}\right]_{\mathrm{n}}$ polypeptides

Chemical characterization of conjugates

Secondary structure characterization

Transmission electron microscopy analysis

References 


\section{Materials and methods}

DNA constructs. The double-stranded oligonucleotide 1 (Figure S1a) encoding two copies of the octapeptide repeating unit $\left[(\mathrm{AG})_{3} \mathrm{EG}\right]_{2}$ was designed with the following considerations: (i) avoidance of codons with a low frequency of occurrence in E. coli, (ii) minimization of sequence repetitiveness and (iii) non-palindromic overhangs for unidirectional multimerization. The plasmid pSK-JS2 was prepared by ligation of the 66-bp oligonucleotide 2 into the EcoRI and BamHI site of pBluescript ${ }^{\circledR}$ II SK (-) (Stratagene). Digestion of pSK-JS2 with BspMI allowed directional insertion of multimerized oligonucleotide 1 (Figure S1b). The desired multimeric gene can subsequently be cloned into the BamHI site of the pET-3b expression vector.

a) Synthetic oligonucleotide 1

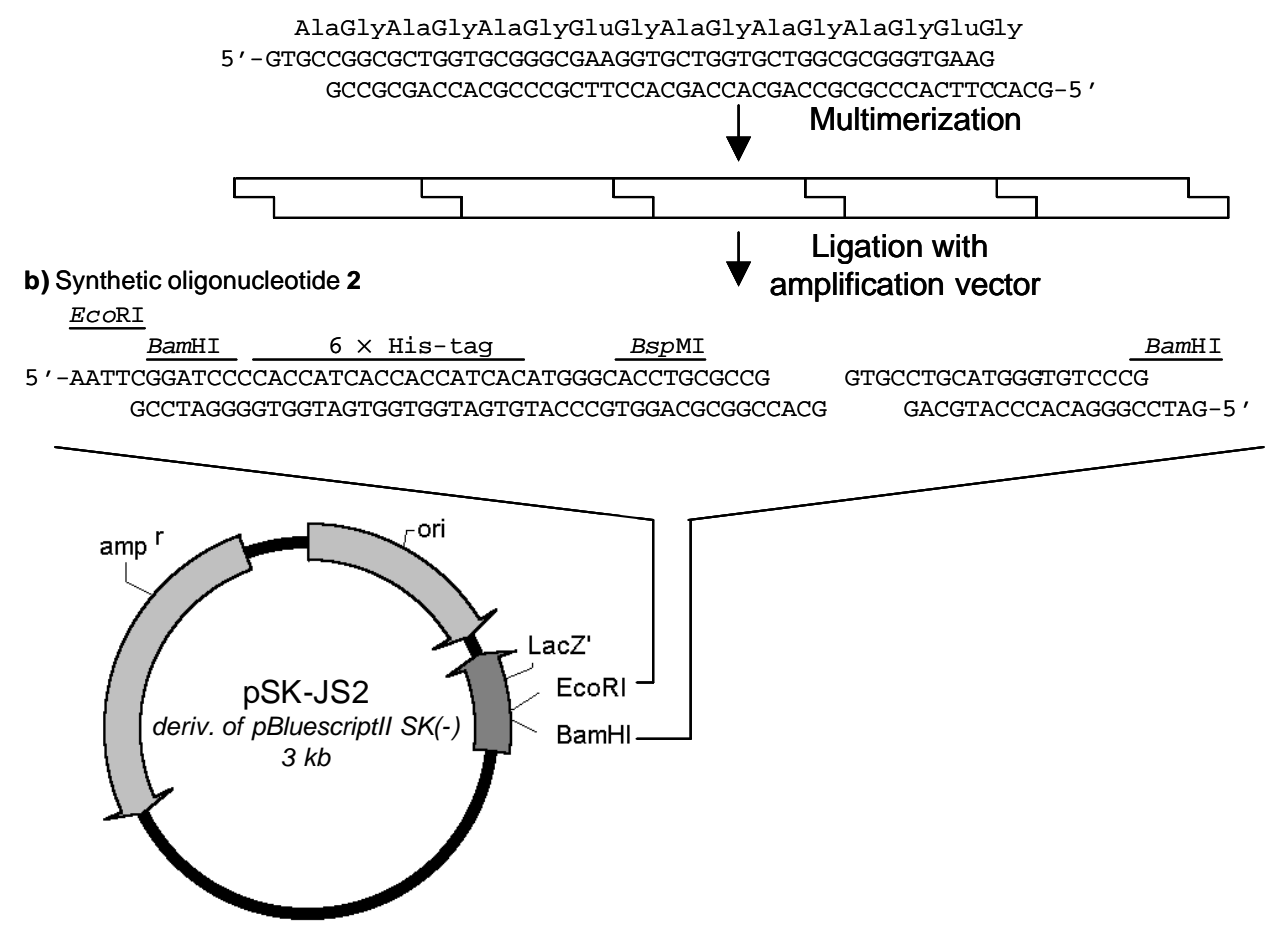

Figure S1. Cloning strategy for $\left[(\mathrm{AG})_{3} \mathrm{EG}\right]_{\mathrm{n}}$ polypeptides. A. Sequence and multimerisation of synthetic oligonucleotide 1 coding for 2 octapeptide repeats. B. The amplification plasmid pSK-JS2 was made by cloning of synthetic oligonucleotide 2 into the EcoRI and BamHI site of pBluescript ${ }^{\circledR}$ II SK (-). After digestion of this plasmid with $B s p \mathrm{MI}$ the multimeric gene was introduced. Finally the sequence was transferred to the $\mathrm{pET}$ - $3 \mathrm{~b}$ expression vector using BamHI (not shown).

Expression and purification protocol. The pET-3b expression vectors carrying the artificial genes coding for 10 or 20 repeats of the octapeptide sequence (AG) ${ }_{3} \mathrm{EG}$ were transformed to BL21(DE3)pLysS cells (Novagen Inc., Madison, USA) and grown overnight at $30^{\circ} \mathrm{C}$. A single colony was used to inoculate $250 \mathrm{ml} 2 \times$ YT medium containing $100 \mu \mathrm{g} / \mathrm{ml}$ ampicillin, 34 $\mu \mathrm{g} / \mathrm{ml}$ chloramphenicol and $1 \%$ glucose. After growth overnight at $30{ }^{\circ} \mathrm{C}$ this preculture was 
used to inoculate $4.5 \mathrm{~L}$ of $2 \times \mathrm{YT}$ medium to $\mathrm{OD}=0.1$ and cells were grown at $37^{\circ} \mathrm{C}$. Protein expression was induced during logarithmic growth by addition of IPTG to a final concentration of $1 \mathrm{mM}$. Cells were harvested after 4 hours of expression by centrifugation at $6,000 \times \mathrm{g}$ for 15 minutes at $4{ }^{\circ} \mathrm{C}$. Cells were resuspended in $50 \mathrm{ml}$ lysis buffer $\left(50 \mathrm{mM} \mathrm{NaH} \mathrm{PO}_{4}(\mathrm{pH} 8.0), 300\right.$ $\mathrm{mM} \mathrm{NaCl}, 10 \mathrm{mM}$ imidazole, $10 \mathrm{mM} \beta$-mercaptoethanol and $1 \mathrm{mM}$ PMSF). Cells were disrupted by sonication on ice for 5 minutes using a $250 \mathrm{~W}$ Branson sonicator (50\% duty cycle, 5 units power). RNase A $(10 \mu \mathrm{g} / \mathrm{ml})$ and DNase I $(5 \mu \mathrm{g} / \mathrm{ml})$ were added followed by incubation on ice for 15 minutes. The lysate was centrifuged at $10,000 \times \mathrm{g}$ for 30 minutes to pellet the cellular debris. The supernatant was incubated with $5 \mathrm{ml} \mathrm{Ni-NTA}$ agarose beads (Qiagen) for 1 hour at $4{ }^{\circ} \mathrm{C}$. The suspension was then loaded onto the column followed by washing with $40 \mathrm{ml}$ wash buffer (as lysis buffer, except $20 \mathrm{mM}$ imidazole). The protein was eluted with $10 \mathrm{ml}$ elution buffer containing $200 \mathrm{mM}$ imidazole. For $\left[(\mathrm{AG})_{3} \mathrm{EG}\right]_{20}$ the eluate was heated for 10 minutes at $70{ }^{\circ} \mathrm{C}$ followed by centrifugation at $6,000 \times \mathrm{g}$ for 15 minutes. Gel filtration chromatography with a Superdex-75 Hi-Load ${ }^{\mathrm{TM}}$ 26/60 column (Amersham Biosciences) resulted in the final purified product (eluent: $50 \mathrm{mM} \mathrm{NaH}_{2} \mathrm{PO}_{4}(\mathrm{pH} 8.0), 150 \mathrm{mM} \mathrm{NaCl}, 10 \mathrm{mM}$ $\beta$-mercaptoethanol; flow $2 \mathrm{ml} / \mathrm{min}$; room temperature). Finally, the product was dialysed against demi-water using a dialysis membrane with a molecular weight cut-off of 3,500 Da (Spectrapor) for 2 days and lyophilized.

CNBr cleavage. Protein was dissolved in $70 \%$ formic acid $(2 \mathrm{mg} / \mathrm{ml})$ and an equal volume of $\mathrm{CNBr}$ in $70 \%$ formic acid $(100 \mathrm{mg} / \mathrm{ml})$ was added followed by incubation on a rotary arm for 2 days at room temperature in the dark. ${ }^{[1]}$ The samples were dried in a centrifugal dryer at room temperature. The pellets were redissolved in demi-water and dialyzed for 2 days against demiwater using a dialysis membrane with a molecular weight cut-off of 3,500 Da (Spectrapor).

Crystallization experiments. Crystallization was induced by vapor diffusion of methanol into a $70 \%$ formic acid $10 \mathrm{mg} / \mathrm{ml}$ protein solution. This was achieved by placing an eppendorf tube with protein solution $(100 \mu \mathrm{l})$ in a bigger container filled with $20 \mathrm{ml}$ methanol. Gelation was observed after 2 days.

NMR spectroscopy. ${ }^{1} \mathrm{H}$ NMR spectra were recorded on a Varian Inova-400 instrument at 298 $\mathrm{K}$. Chemical shifts are reported in ppm relative to the $\mathrm{H}_{2} \mathrm{O}$ signal $(4.79 \mathrm{ppm}) .{ }^{13} \mathrm{C}$ NMR spectra were recorded on a Bruker AC-300 instrument at $298 \mathrm{~K}$. 
Maldi-TOF analysis of conjugates. MALDI-TOF-MS spectra were measured on a Bruker Biflex III spectrometer. Samples were dissolved in water/acetonitrile (1:1 v/v) containing 1\% trifluoroacetic acid and mixed in a 1:1 ratio with a solution of $20 \mathrm{mg} / \mathrm{ml}$ of sinapinic acid in the same solvent and spotted on a MALDI-plate.

Infrared and circular dichroism spectroscopy. IR spectra were recorded on a Thermo Mattson Genesis IR-300 spectrometer equipped with an ATR cell. Circular dichroism spectroscopy was performed on a Jasco J-810 spectropolarimeter (band width: 1nm, response: 1 sec., sensitivity: standard, 1 range: $260-180 \mathrm{~nm}$, data pitch: $0.5 \mathrm{~nm}$, scanning speed: 100 $\mathrm{nm} / \mathrm{min}$, accumulation: 5). 


\section{Protein expression and purification}

The expression and purification of cysteine-flanked $\left[(\mathrm{AG})_{3} \mathrm{EG}\right]_{10}$ and $\left[(\mathrm{AG})_{3} \mathrm{EG}\right]_{20}$ is depicted in Figure S2a and S2b, respectively. Lanes 1 and 2 show the total protein content before and after induction with IPTG. The expression levels of both proteins were low and therefore T7 tag Western blot analysis was used to follow the purification of both proteins (not shown). Both proteins were present in the soluble fraction of the lysate (lane3). Lane 5 shows the purity after native Ni-NTA purification. For $\left[(\mathrm{AG})_{3} \mathrm{EG}\right]_{20}$ the purity could be increased substantially by heating the sample for 10 minutes at $70{ }^{\circ} \mathrm{C}$ which resulted in the precipitation of endogenous $E$. coli protein whereas the protein of interest remained soluble (Figure S2b, lane 6). The molecular weight, as determined by electrophoresis, were higher than theoretically predicted, due to the highly acidic nature of these polypeptides. The anomalous behaviour of highly acidic proteins has been described before by Mc Grath et al. ${ }^{[2]}$ The expected molecular weights of 11.1 $\mathrm{kDa}$ for $\left[(\mathrm{AG})_{3} \mathrm{EG}\right]_{10}$ and $16.8 \mathrm{kDa}$ for $\left[(\mathrm{AG})_{3} \mathrm{EG}\right]_{20}$ were confirmed my MALDI-TOF mass spectrometry. In addition to the full-length protein we observed for both $\left[(\mathrm{AG})_{3} \mathrm{EG}\right]_{10}$ and $\left[(\mathrm{AG})_{3} \mathrm{EG}\right]_{20}$ the presence of truncated product at the height of the $21 \mathrm{kDa}$ molecular weight marker. Western blot analysis showed that this product contained the N-terminus of the desired protein. Maldi-TOF analysis indicated that this band is not a discrete protein product, but a mixture of truncated products from $5.9 \mathrm{kDa}$ to $6.9 \mathrm{kDa}$. These truncated products were removed using gel filtration chromatography (Figure S2a, lane 6 and Figure S2b, lane 7). Isolated yields for $\left[(\mathrm{AG})_{3} \mathrm{EG}\right]_{10}$ and $\left[(\mathrm{AG})_{3} \mathrm{EG}\right]_{20}$ were $6 \mathrm{mg} / \mathrm{L}$ culture and $3 \mathrm{mg} / \mathrm{L}$, respectively.

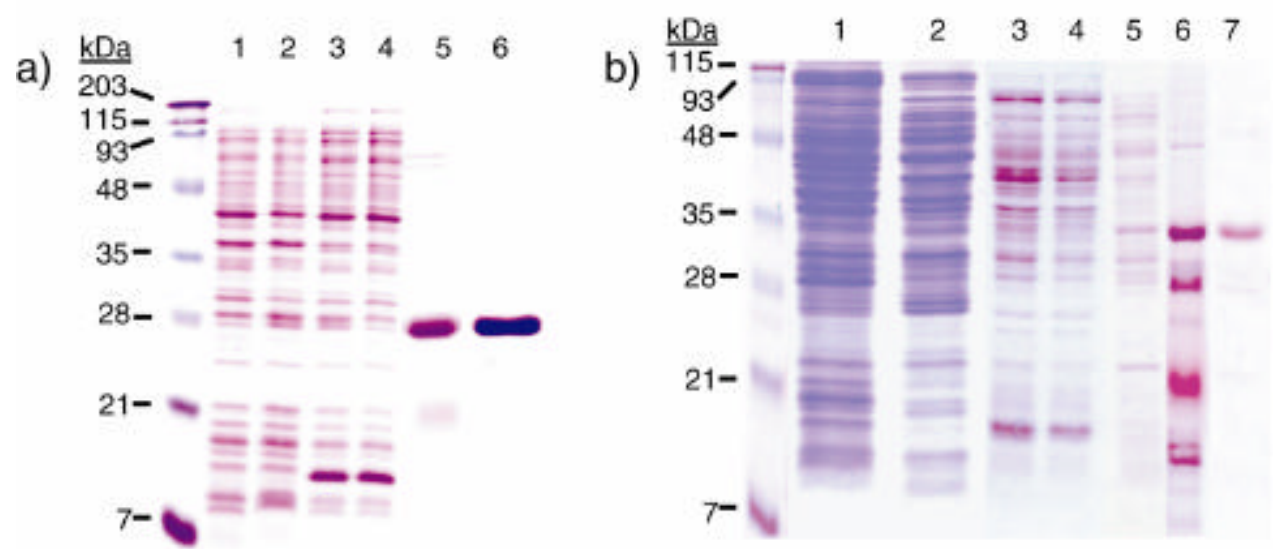

Figure S2. SDS-PAGE analysis of expression and purification of $\left[(\mathrm{AG})_{3} \mathrm{EG}\right]_{\mathrm{n}}$ polypeptides (15\% acrylamide, staining with Coomassie Brilliant Blue R-250). a) $\left[(\mathrm{AG})_{3} \mathrm{EG}\right]_{10}$. Lane 1 and 2: whole cell lysate of E. coli BL21(DE3)pLysS uninduced and 3 hours after induction with IPTG; lane 3: clarified soluble fraction of lysate; lane 4: flow-through of NiNTA column; lane 5 elution fraction of Ni-NTA column; lane 6: protein after purification with Superdex-75 column. b) $\left[(\mathrm{AG})_{3} \mathrm{EG}\right]_{20}$. Lane 1-5: as a); lane 6: soluble fraction after heating for 10 minutes at $70{ }^{\circ} \mathrm{C}$; lane 7 : protein after purification with Superdex-75 column. 
Synthesis of maleimide-functionalized poly(ethylene glycol)-750

Poly(ethylene glycol)-750 monofunctionalized with an amine group was purchased from Rapp Polymere GmbH (Tübingen, Germany). $391 \mathrm{mg}$ PEG-750- $\mathrm{NH}_{2}(0.52 \mathrm{mmol})$ was dried by azeotropic evaporation with benzene. The dried product was dissolved in $5 \mathrm{ml}$ DMF together with $110 \mathrm{mg}$ E-maleimidocaproic acid (0.52 mmol; Sigma), $230 \mathrm{mg}$ BOP coupling reagent (0.52 mmol ; benzotriazole-1-yl-oxy-tris-(dimethylamino)-phosphonium hexafluorophosphate; Advanced Chemtech) and $192 \mathrm{mg}$ diisopropylethylamine (1.60 mmol; Fluka). After 24 hours stirring at room temperature DMF was evaporated and the resulting solid was redissolved in dichloromethane. This solution was subsequently extracted with $1 \mathrm{~N} \mathrm{HCl}(2 \times)$, water, $5 \%$ $\mathrm{NaHCO}_{3}(2 \times)$, water and saturated $\mathrm{NaCl}$. After evaporation the product was further purified with a Sephadex LH-20 gel filtration column (resin from Amersham Biosciences) using methanol/dichloromethane $1: 1 \mathrm{v} / \mathrm{v}$ as eluent. The final yield was $217 \mathrm{mg}$ pure product $(0.35$ mmol, 68\%). $\mathrm{R}_{\mathrm{f}}=0.60-0.75$ (methanol/chloroform $=1: 4 \mathrm{v} / \mathrm{v}$, maleimide detection); ${ }^{1} \mathrm{H}$ NMR $\left(400 \mathrm{MHz}, \mathrm{CDCl}_{3}\right):{ }^{1} \mathrm{H} \mathrm{NMR}\left(400 \mathrm{MHz}, \mathrm{CDCl}_{3}\right): \delta=6.69$ (s, $\left.2 \mathrm{H}, \mathrm{CH}=\mathrm{CH}\right), 6.27(\mathrm{br} \mathrm{s}, 1 \mathrm{H}$, $\mathrm{NHCO}$ ), 3.61-3.68 (br m, 60H, O $\left(\mathrm{CH}_{2}\right)_{2} \mathrm{O}$ ), 3.55 (t, $2 \mathrm{H}, \mathrm{CH}_{2} \mathrm{CH}_{2} \mathrm{NHCO}$ ), 3.51 (t, $2 \mathrm{H}, \mathrm{NCH}_{2}$ ), $3.44\left(\mathrm{~m}, 2 \mathrm{H}, \mathrm{CH}_{2} \mathrm{NHCO}\right), 3.38\left(\mathrm{~s}, 3 \mathrm{H}, \mathrm{CH}_{3} \mathrm{O}\right), 2.17\left(\mathrm{t}, 2 \mathrm{H}, \mathrm{CH}_{2} \mathrm{CONH}\right), 1.66(\mathrm{~m}, 2 \mathrm{H}$, $\left.\mathrm{NHCOCH}_{2} \mathrm{CH}_{2}\right), 1.60\left(\mathrm{~m}, 2 \mathrm{H}, \mathrm{CH}_{2} \mathrm{CH}_{2} \mathrm{~N}\right), 1.31\left(\mathrm{~m}, 2 \mathrm{H}, \mathrm{CH}_{2} \mathrm{CH}_{2} \mathrm{CH}_{2} \mathrm{CH}_{2} \mathrm{~N}\right) ;{ }^{13} \mathrm{C}$ NMR $(75$ $\left.\mathrm{MHz}, \mathrm{CDCl}_{3}\right): \delta=172.1(1 \mathrm{C}, \mathrm{CONH}), 163.8(2 \mathrm{C}, \mathrm{NCO}), 133.5(2 \mathrm{C}, \mathrm{C}=\mathrm{C}), 71.6(1 \mathrm{C}$, $\left.\mathrm{CH}_{2} \mathrm{CH}_{2} \mathrm{NH}\right), 70.2\left(30 \mathrm{C}, \mathrm{O}\left(\mathrm{CH}_{2}\right)_{2} \mathrm{O}\right), 58.7\left(1 \mathrm{C}, \mathrm{CH}_{3} \mathrm{O}\right), 38.9\left(1 \mathrm{C}, \mathrm{CH}_{2} \mathrm{NH}\right), 37.5\left(1 \mathrm{C}, \mathrm{CH}_{2} \mathrm{~N}\right)$, $36.1\left(1 \mathrm{C}, \mathrm{CH}_{2} \mathrm{CONH}\right), 28.1 \quad\left(1 \mathrm{C}, \mathrm{CH}_{2} \mathrm{CH}_{2} \mathrm{~N}\right), 26.2\left(1 \mathrm{C}, \mathrm{CH}_{2} \mathrm{CH}_{2} \mathrm{CH}_{2}\right), 24.9$ (1C, $\mathrm{CH}_{2} \mathrm{CH}_{2} \mathrm{CONH}$ ); MS (MALDI-TOF): Calcd. for $\mathrm{n}=15, \mathrm{C}_{43} \mathrm{H}_{80} \mathrm{~N}_{2} \mathrm{O}_{19}[\mathrm{M}+\mathrm{Na}]^{+}$: 952.05, found $\mathrm{m} / \mathrm{z}=951.70, \mathrm{M}_{\mathrm{n}}=1045, \mathrm{M}_{\mathrm{w}} / \mathrm{M}_{\mathrm{n}}=1.01$.

Conjugation of PEG-750-maleimide to $\left[(\mathrm{AG})_{3} \mathrm{EG}\right]_{\mathrm{n}}$ polypeptides

$10 \mathrm{mg}$ of freeze-dried protein was dissolved in $5 \mathrm{ml} 20 \mathrm{mM} \mathrm{NaH} \mathrm{PO}_{4}$ buffer ( $\mathrm{pH}$ 8.0) containing $150 \mathrm{mM} \mathrm{NaCl}, 1 \mathrm{mM}$ EDTA and $200 \mathrm{mM}$ dithiotreitol (DTT) and incubated for 1 hour at room temperature. The protein was precipitated by addition of 0.25 volumes of ice-cold $100 \%$ trichloroacetic acid (TCA), followed by incubation at $-20{ }^{\circ} \mathrm{C}$ for 30 minutes. After centrifugation at $13000 \mathrm{rpm}$ for 10 minutes at $4{ }^{\circ} \mathrm{C}$ the pellet was washed with $2.5 \mathrm{ml}$ ice-cold $20 \%$ TCA followed by a second wash of $2.5 \mathrm{ml} 1 \%$ TCA for $\left[(\mathrm{AG})_{3} \mathrm{EG}\right]_{10}$ and $2.5 \mathrm{ml}$ milli-Q for $\left[(\mathrm{AG})_{3} \mathrm{EG}\right]_{20}$. After each wash the solution was centrifuged for 5 minutes at $4{ }^{\circ} \mathrm{C}$. The pellet was redissolved in $5 \mathrm{ml} 100 \mathrm{mM} \mathrm{NaH}_{2} \mathrm{PO}_{4}$ buffer (pH 6.8) containing $150 \mathrm{mM} \mathrm{NaCl}$. The thiol 
content of this solution was determined using the Ellman's essay ${ }^{[3]}$ : The thiol content for $\left[(\mathrm{AG})_{3} \mathrm{EG}\right]_{10}$ and $\left[(\mathrm{AG})_{3} \mathrm{EG}\right]_{20}$ was determined to be respectively a factor 1.4 and 1.8 times higher than the theoretical thiol content, indicating the presence of residual DTT. For complete PEGylation of the cysteine residues an excess of maleimide functionalised poly(ethylene glycol $)\left(M_{n}=750 \mathrm{~g} / \mathrm{mol}\right)$ was immediately added as a $5 \mathrm{ml}$ solution in the same buffer. For $\left[(\mathrm{AG})_{3} \mathrm{EG}\right]_{10}$ a 5 -fold excess was used whereas a 20 -fold excess was used for $\left[(\mathrm{AG})_{3} \mathrm{EG}\right]_{20}$. The reaction mixture was incubated overnight on a rotating arm.

Ni-NTA chromatography was used to remove the excess poly(ethylene glycol). The NiNTA beads were pre-equilibrated in $100 \mathrm{mM} \mathrm{NaH}_{2} \mathrm{PO}_{4}$ buffer $(\mathrm{pH} \mathrm{8.0)}$ containing $150 \mathrm{mM}$ $\mathrm{NaCl}$. The PEG-conjugation reaction was added to $10 \mathrm{ml}$ equilibrated $50 \% \mathrm{Ni}$-NTA suspension and incubated for 1 hour at room temperature. The suspension was centrifuged for 5 minutes at $1500 \mathrm{rpm}$ and the supernatant was removed. $10 \mathrm{ml}$ wash buffer $\left(100 \mathrm{mM} \mathrm{NaH}_{2} \mathrm{PO}_{4}(\mathrm{pH} \mathrm{8.0})\right.$, $150 \mathrm{mM} \mathrm{NaCl}$ ) was added and a column was loaded. The beads were washed until all the poly(ethylene glycol) was removed (monitored by measuring absorption profile at $214 \mathrm{~nm}$ ). Subsequently the protein-PEG conjugate was eluted by increasing the imidazole concentration to $200 \mathrm{mM}$. Finally, the product was dialysed for 2 days against demi-water using a dialysis membrane (MWCO = 3,500 Da; Spectrapor) and lyophilized. SDS-polyacrylamide gel electrophoresis showed that the attachment of PEG-chains resulted in a different electrophoretic mobility for both proteins (Figure S3). Noteworthy is the different effect of the attachment of poly(ethylene glycol)-750 on the electrophoretic mobility of the conjugates. For $\left[(\mathrm{AG})_{3} \mathrm{EG}\right]_{10}$ the band shifted to a lower apparent molecular weight, whereas the opposite was the case for $\left[(\mathrm{AG})_{3} \mathrm{EG}\right]_{20}$. 


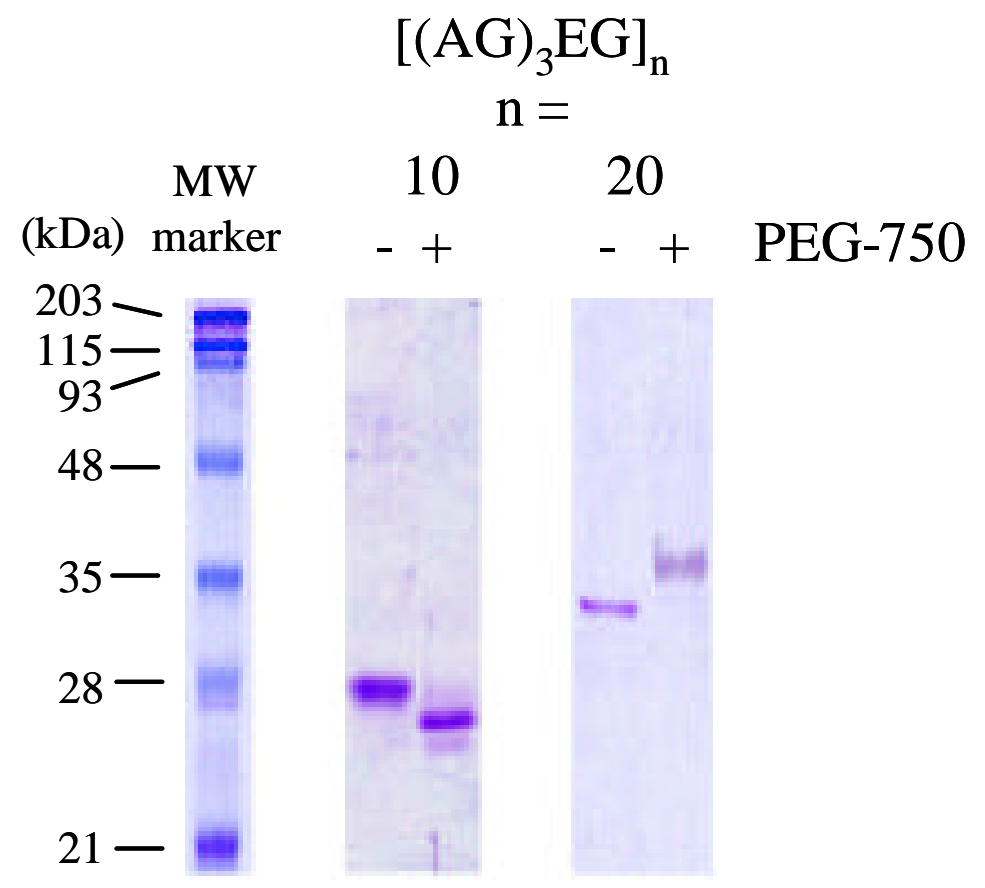

Figure S3. SDS-PAGE analysis of conjugation of PEG-750-maleimide with $\left[(\mathrm{AG})_{3} \mathrm{EG}\right]_{10}$ and $\left[(\mathrm{AG})_{3} \mathrm{EG}\right]_{20}$.

\section{Chemical characterization of conjugates}

${ }^{1} \mathbf{H}$ NMR spectroscopy. The conjugates were dissolved in $\mathrm{D}_{2} \mathrm{O}$. The ${ }^{1} \mathrm{H}$ NMR spectrum of conjugates of $\left[(\mathrm{AG})_{3} \mathrm{EG}\right]_{10}$ and $\left[(\mathrm{AG})_{3} \mathrm{EG}\right]_{20}$ with PEG-750 are depicted in Figure S4a and S4b, respectively.

For $\left[(\mathrm{AG})_{3} \mathrm{EG}\right]_{10}$ reacted with PEG-750-maleimide the following (major) signals could be assigned: $\delta=1.40(\mathrm{~d}, 120 \mathrm{H}$, Ala-H $\beta$ ), $2.10(\mathrm{~m}, 26 \mathrm{H}$, Glu-H $\beta), 2.26(\mathrm{~m}, 26 \mathrm{H}, \mathrm{Glu}-\mathrm{H} \gamma), 3.40$

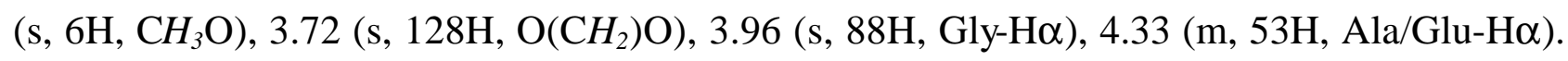
To determine the efficiency of conjugation with poly(ethylene glycol) and the subsequent removal of excess non-reacted poly(ethylene glycol), the signal intensity of the methyl group of alanine $(\mathrm{Ala}-\mathrm{H} \beta$ ) was compared to the signal intensity of the repeating ethyleneoxide units $\left(\mathrm{O}\left(\mathrm{CH}_{2}\right)_{2} \mathrm{O}\right)$ of poly(ethylene glycol). The ethylene oxide signal was 1.2 times the expected value and therefore in reasonable agreement with the attachment of two poly(ethylene glycol) chains per protein molecule (Figure S4a).

For $\left[(\mathrm{AG})_{3} \mathrm{EG}\right]_{20}$ reacted with PEG-750-maleimide the following signals could be

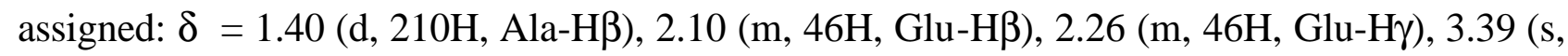

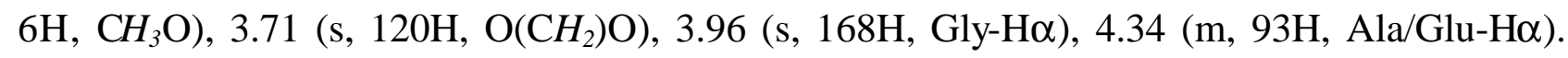
Comparison of the ethylene oxide signal with the methyl group of alanine showed that the ethylene oxide signal was 1.4 times the expected value (Figure S4B). 
a)

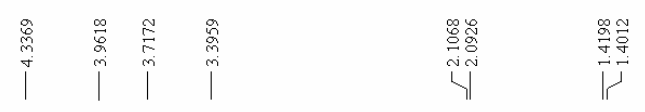

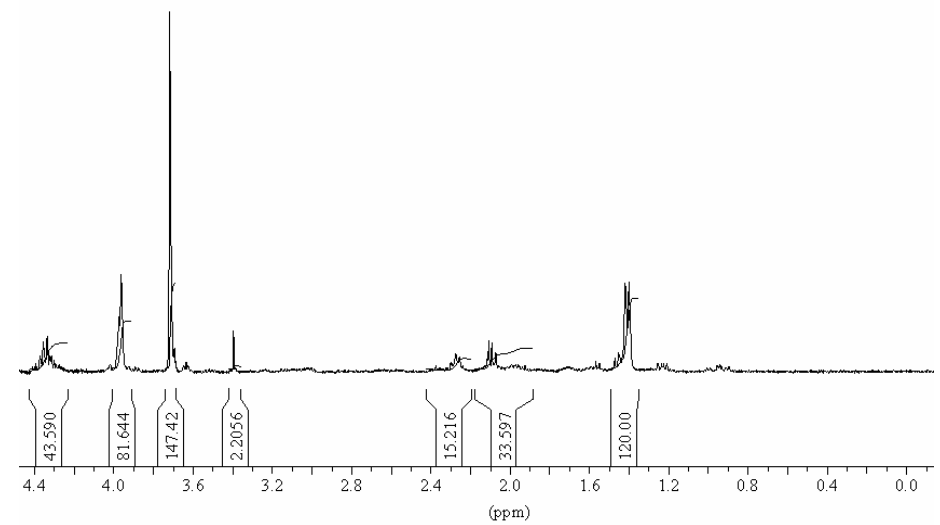

b)
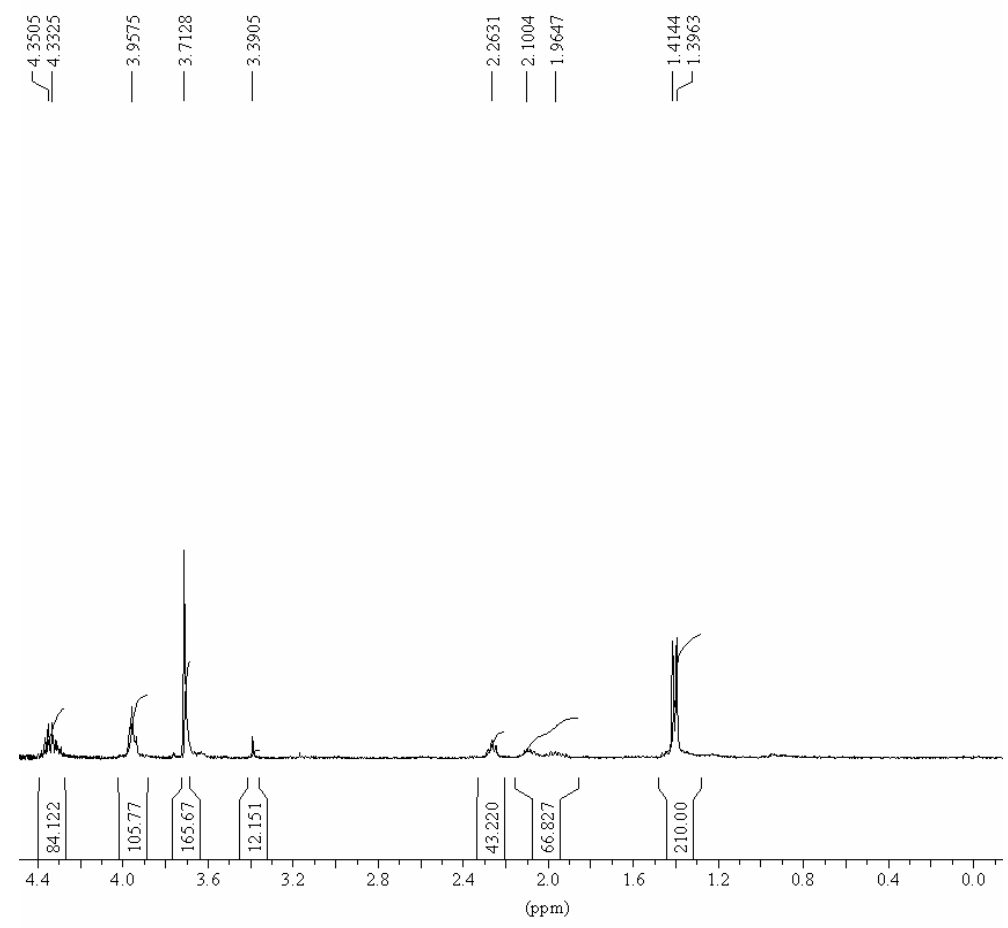

Figure S4. $400 \mathrm{MHz}{ }^{1} \mathrm{H}$ NMR spectrum of PEG- $\left[(\mathrm{AG})_{3} \mathrm{EG}\right]_{\mathrm{n}}-\mathrm{PEG}$ : a) $\mathrm{n}=10$ and b) $\mathrm{n}=20$. Solvent: $\mathrm{D}_{2} \mathrm{O}$. 
Maldi-TOF mass spectrometry. The main peak after conjugation of maleimide-functionalized PEG-750 was observed at $13280 \mathrm{Da}$ which is in agreement with the attachment of two PEGchains (calculated mass 13202). After cyanogen bromide cleavage the main peak was observed at $8529 \mathrm{Da}$ in good agreement with the theoretical mass of $8508 \mathrm{Da}$. For $\left[(\mathrm{AG})_{3} \mathrm{EG}\right]_{20}$ a molecular ion was observed at m/z $16811(1+)($ expected value $=16817)$. Upon conjugation with maleimide-functionalized poly(ethylene glycol) a shift in mass was observed in agreement with the conjugation of two PEG-chains (observed m/z 18679). In addition a smaller peak (m/z 19807) was observed which could indicate the attachment of three PEG-chains, possibly caused by attachment to a lysine residue on the C-terminal side of the protein.

\section{Secondary structure characterization}

Infrared spectroscopy. Infrared spectra were recorded by pipetting the gelated sample in methanol $(1 \mathrm{mg} / \mathrm{ml})$ on the surface of the ATR crystal followed by drying. The IR spectra of PEG- $\left[(\mathrm{AG})_{3} \mathrm{EG}\right]_{10}$-PEG conjugates exhibited strong amide I and II vibrational modes at $\sim 1623$ $\mathrm{cm}^{-1}$ and $\sim 1522 \mathrm{~cm}^{-1}$, characteristic of the $\beta$-sheet conformation ${ }^{[4]}$, whereas the weak amide I component observed at $\sim 1697 \mathrm{~cm}^{-1}$ indicated its antiparallel nature (Figure S5a) ${ }^{[5]}$. Similar spectra were recorded for PEG- $\left[(\mathrm{AG})_{3} \mathrm{EG}\right]_{20}$-PEG (Figure S5b). We can conclude that the antiparallel $\beta$-sheet structure is retained upon conjugation of poly(ethylene glycol). The amide I band around $1654 \mathrm{~cm}^{-1}$ (and also amide II bands around 1550, not indicated) indicates that some fraction of the polypeptide chain has adopted a secondary structure other than that of the antiparallel $\beta$-sheet. The amide I component has been assigned previously to reverse turns of the $\beta$ or $\gamma$ type $^{[6]}$, but may also partly result from a random coil/ $\alpha$-helical conformation. 

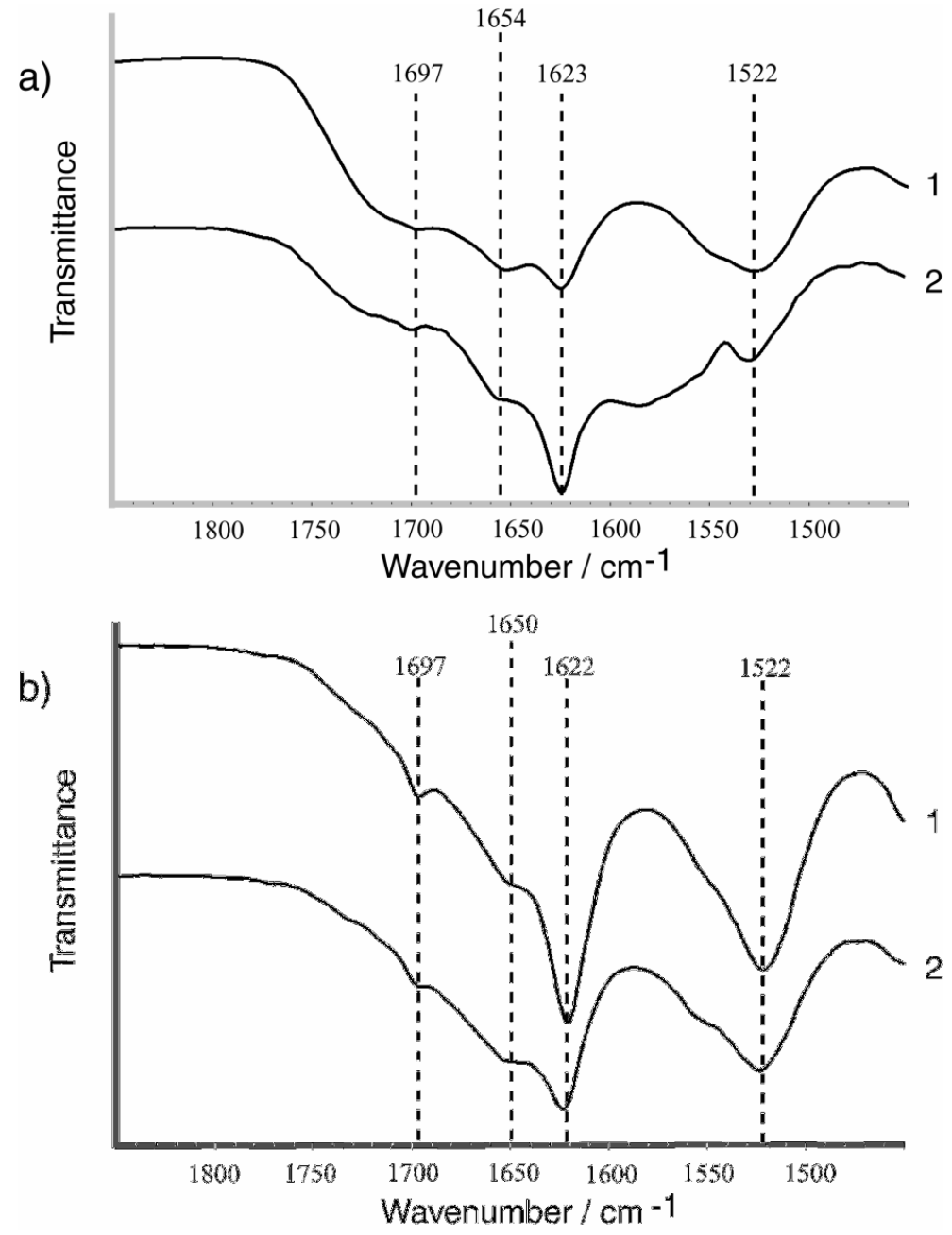

Figure S5. ATR-infrared spectra of PEG- $\left[(\mathrm{AG})_{3} \mathrm{EG}\right]_{\mathrm{n}}-\mathrm{PEG}$ conjugates in amide I and amide II regions for a) $\mathrm{n}=10: 1$ ) uncleaved 2) $\mathrm{CNBr}$ cleaved $b) \mathrm{n}=20$ : 1) uncleaved 2) $\mathrm{CNBr}$ cleaved.

Circular dichroism spectroscopy. CD spectroscopy was performed on PEG-[(AG) $\left.)_{3} \mathrm{EG}\right]_{20^{-}}$ PEG conjugates. Only the uncleaved variant gave a strong CD-effect and confirmed the $\beta$-sheet conformation with a negative ellipticity at $215 \mathrm{~nm}$ and a positive ellipticity at $195 \mathrm{~nm}$ (Figure S6). ${ }^{[7]}$ 


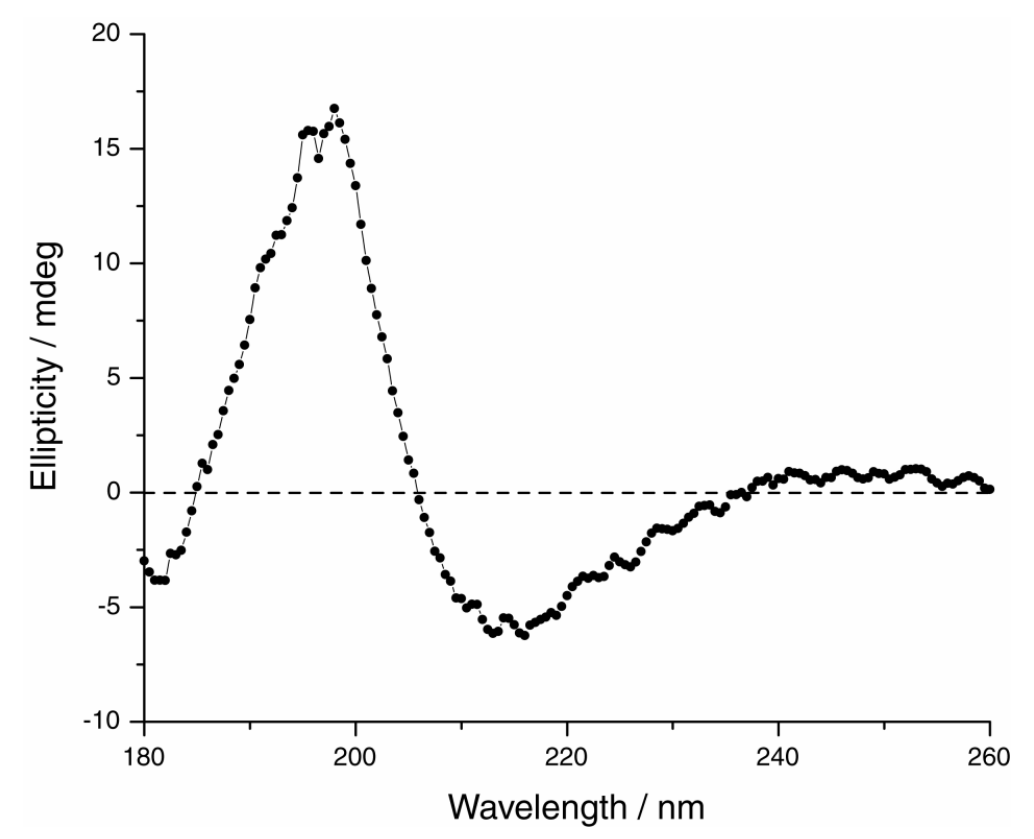

Figure S6. Circular dichroism spectrum of uncleaved PEG- $\left[(\mathrm{AG})_{3} \mathrm{EG}\right]_{20}$-PEG conjugate $\left(\mathrm{T}=20{ }^{\circ} \mathrm{C}\right) .50 \mu \mathrm{l}$ crystallized sample (1 mg/ml in methanol) was applied to a quartz surface and allowed to dry.

\section{Transmission electron microscopy analysis}

For the proteins without conjugated poly(ethylene glycol) only few individual fibres were found, which is most likely the result of the formation of bigger aggregated structures, due to increased interaction between the $\beta$-sheet polypeptides. TEM images for uncleaved and $\mathrm{CNBr}$ cleaved samples of $\left[(\mathrm{AG})_{3} \mathrm{EG}\right]_{20}$ are depicted in Figure S7a and b, respectively. TEM analysis of $\left[(\mathrm{AG})_{3} \mathrm{EG}\right]_{36}$ by Krejchi et al. ${ }^{[6]}$ showed crystalline platelets of $\sim 2000 \AA$ (assigned as a) by $150 \AA$ (assigned as b) by about 40 to $100 \AA$ (from shadow lengths; assigned as c). No indication of similar platelets were found in our samples.

a)

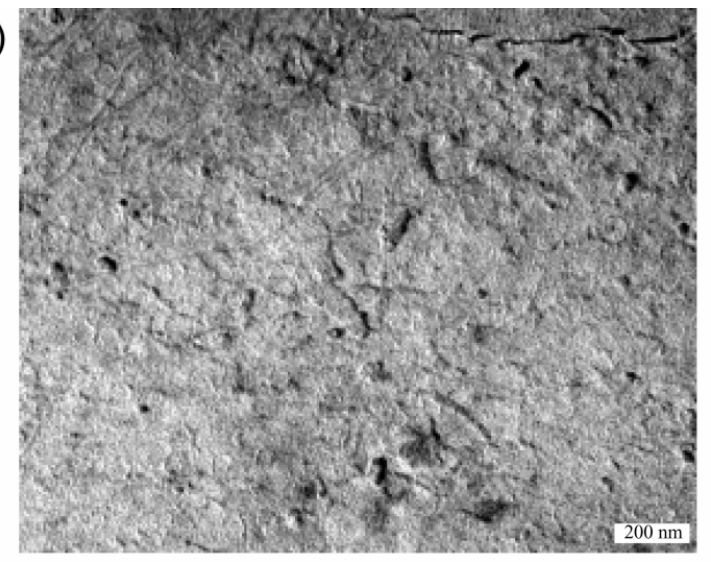

b)

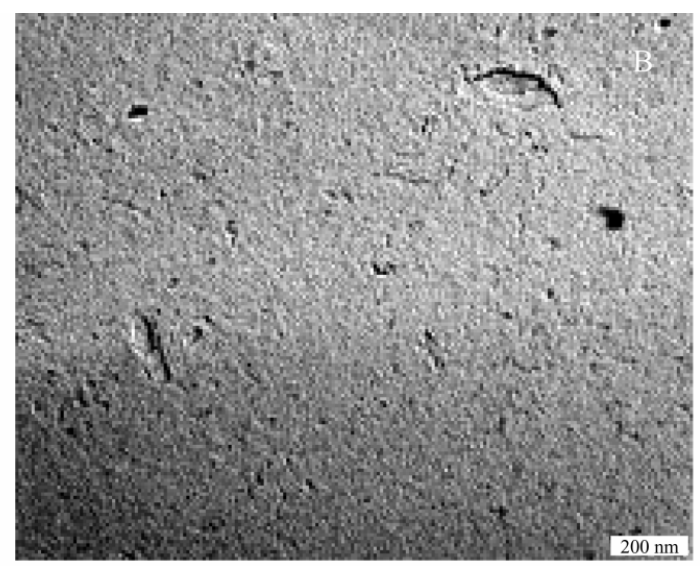

Figure S7. TEM micrographs of crystallized $\left[(\mathrm{AG})_{3} \mathrm{EG}\right]_{\mathrm{n}}$ polypeptides without conjugated poly(ethylene glycol)-750. Platinum shadowed samples $(1 \mathrm{mg} / \mathrm{ml})$ of a) uncleaved $\left[(\mathrm{AG})_{3} \mathrm{EG}\right]_{20} ;$ b) $\mathrm{CNBr}$ cleaved $\left[(\mathrm{AG})_{3} \mathrm{EG}\right]_{20}$. 


\section{References}

[1] F. Ausubel, R. Brent, R. Kingston, D. Moore, J. Seidman, J. Smith, K. Struhl, Current protocols in molecular biology, volume 3, sec. 16.4.13, Vol. 16.4.13, John Wiley \& sons, New York, 1999.

[2] K. P. McGrath, M. J. Fournier, T. L. Mason, D. A. Tirrell, J. Am. Chem. Soc. 1992, 114, 727.

[3] G. L. Ellman, Arch. Bioch. Biophys. 1959, 82, 70.

[4] S. Krimm, J. Bandekar, Adv. Protein Chem. 1986, 38, 181.

[5] M. Miyazawa, E. R. Blout, J. Am. Chem. Soc. 1960, 83, 712.

[6] M. T. Krejchi, E. D. T. Atkins, A. J. Waddon, M. J. Fournier, T. J. Mason, D. A. Tirrell, Science 1994, 265, 1427.

[7] N. Greenfield, G. D. Fasman, Biochemistry 1969, 8, 4108. 